\title{
From the Depths I Will Rise: On Being Buried Alive and Survival Anonymous
}

Several months ago I experienced something that I hope few will ever Sexperience: I left a Supermax Prison in Colorado after spending 56 months in long-term solitary confinement. I had been buried alive, locked away from others. At first I was placed in 'the hole' because prison officials had deemed me too dangerous to be around others. Later, paperwork snafus and the release process kept me in my small cell until the day of my release. After so long in a sensory vacuum, I would find as much punishment from the first days of my release as I did from solitary. After all those years, the sights and sounds I had missed, the lack of people and touch, and even a simple conversation created a feeling of sensory overload.

The world of solitary confinement is an environment with detrimental effects that few people can comprehend. It was an experience that in a small way was like Phillip Zimbardo's infamous "Stanford Prison Experiment". However, this was no experiment. It was real life - no escape, no calling an end to anything because the subjects were going crazy, and no safety if you chose to complain that the authority figures were behaving immorally or unethically.

I sat by myself in a twelve-by-eight foot cell. I was a witness to mental abuse, physical abuse, suicide, literally watching grown men go insane, and on top of all that medical and psychological neglect. There was no escape. I did not have the option of saying "I've had enough" and expect to go home. I was stuck no matter how bad the situation got, no matter how the guards treated me, and no matter if I started to lose my mind. I was stuck with myself and my thoughts - that was it.

The mind does incredible and fascinating things to survive in such environments. I learned to withstand an emotional state and a level of loneliness I could have never even comprehended or understood prior to that experience. I learned very quickly how to be by myself and adapt to that state. I quite literally learned to depend on myself and myself only. I would go several days straight without something as simple as a shower if the facility was on lockdown. Learning to adapt to any and all environments and circumstances is one of the most intriguing and fascinating things I learned my mind and body could do. If you are treated like an animal long enough then you begin to think and act like one - that is what happened to me. I was fed my meals through a small slot in the door, handcuffed and shackled 
before the door was opened to walk to the shower, locked in a cage for several days at a time with no fresh air, never any sunlight and very limited social interaction. Learn to live and depend on yourself or succumb to inner insanity. Being locked behind a steel door with only a small window to the outside world the feeling of hopelessness grows greater. Each and every day I felt less human, because everything that made me human - contact and conversations, walking in sunlight, and even the drive to find personal satisfaction and success - was taken away from me. The absence of other people meant an absence of self.

For me, I believe it is the fundamental purpose of our whole social existence to feel and be felt, to understand and be understood on a personal level, but such happenings do not occur in isolation. For me, the keys to survival were to stay busy with whatever I could find: reading, puzzles and writing letters. Daily exercise acted as a stress reliever and helped to enhance sleep at night. These activities also helped to convince me that I was still a human being with real feelings, emotions and thoughts. These activities gave me purpose to exist and gave me a reason to survive.

I did the same thing at the same time every day for five years. Every day I would wake-up before breakfast and do a small, but intense workout. After breakfast was served I would begin the process of preserving and strengthening my mind. This would normally include reading psychology, philosophy and economics. Around the time I finished my studies lunch would be served. After lunch, I would write a letter or two until lunch was digested. As soon as I was ready I would fill about two hours of my afternoon exercising in my cell. When the workout regimen was fulfilled I would take a "bird bath" in the sink in my cell. After washing up I would write a few more letters. I quickly found that communication to and from the outside world to those I love was my purest form of mental survival. By this time dinner was coming around and I would eat, and then spend the duration of the evening reading my books. Going to sleep early was a small way to guarantee myself some sleep. During the long nights in the box - between the doors constantly opening, guards' speaking over the loudspeakers, and the horrible sounds of people losing their minds and screaming in psychological agony - sleep was a precious commodity.

In spite of all these personal struggles I somehow left that tomb way better than I came in. I was handcuffed, shackled and double-escorted every time I left the cell. I was exposed to 24 hours of light and even flashlights in 
my eyes all night long. I ate and slept alone every day. I survived solitary, despite the harsh realities involved, but I was unfortunately one of the very few. What saved me was my desire to beat the system and show that I would not be broken. My mind became my refuge from the constant void of humanity, and the longer I was without sensory or mental stimulation the easier it was for me to dive into my own thoughts.

My exposure to long-term isolation was an experience of both sensory deprivation and, upon release, sensory overload. The human senses include sight, hearing, taste, smell, and touch, and when these senses are not used or are limited they become stagnant, almost non-reactive to stimuli. Sensory deprivation is a big part of what the authorities think will help to control violent and uncontrollable prisoners. When we are deprived of the sensory stimuli we so desperately need, it actually does the complete opposite of what is said to be intended: it does not tame us, it manufactures madness.

Seeing nothing but the four walls of a cell 24 hours a day not only makes you feel trapped, but it also severely limits the transfer of information to the brain and ultimately can prove to be detrimental to your eyesight. The eerie silence of isolation and the overall lack of auditory stimuli can also hamper and contribute to the loss of hearing. This is the same with taste and smell. As I learned in psychology class, if certain neural pathways and circuits are not used, the brain can lose them. I feel this proves that sensory deprivation can cause several impairments in our brain and senses in general.

My sense of touch was starved of for five long years. Losing the ability to touch and be touched, feel and be felt was the most detrimental part of the experience for me, along with others in my situation. At first you begin to convince yourself that you will do anything for human contact. Anything to feel alive, to feel something, including getting cell extracted just to have that contact. But after a while, when starved of physical contact for so long, you begin to fear it and want nothing to do with it, inducing further isolation not brought on by yourself, but by your environment.

Even the guards did not see us as human. Every guard on pretty much every shift was primed to deal with prisoners using premeditated and calculated humiliation. They called us names, destroyed our cells and private property, and would attempt at every corner to abuse their power and discourage us from communication, medical help, therapy, and visits with lawyers, family, and friends. If we fought back we could lose our already restricted privileges. As psychiatrist Stuart Grassian says, "[i]t's kind of like kicking and beating a dog and keeping it in a cage until it gets 
as crazy and vicious and wild as it can possibly get and then one day you take it out into the middle of the streets of New York or San Francisco and open the cage and you run away. That's no favor to the community or to the person" (Kamel and Kerness, 2003, p. 8). Their treatment of us often made us worse instead of better.

It is well documented and established that isolation and sensory deprivation can cause and enhance or even aggravate a variety of psychiatric symptoms. As documented in a briefing paper by the Humans Rights Watch "prisoners subjected to prolonged isolation may experience depression, despair, anxiety, rage, claustrophobia, hallucinations, problems with impulse control and an impaired ability to think, concentrate or remember" (ibid, p.3). I used to try and read a lot, but could never seem to be able to focus for longer than 30 minutes at a time. Even after long reading sessions I would have great difficulty remembering anything I had just read, which seems consistent with Kamel and Kerness' work.

Stuart Grassian, a lead psychiatrist at the Harvard Medical School and expert in the realm of the psychological impact of Supermax prisons, reports "the courts have recognized that long term solitary confinement itself can cause a very specific kind of psychiatric syndrome, which in its worst stages can lead to an agitated, hallucinatory, confusional state often involving random violence and self-mutilation, suicidal behavior and other agitated and fearful and confusional kinds of symptoms" (ibid). This mental condition is attributed to the sensory deprivation and sensory overload caused by solitary confinement, and this mental snake pit is where I fought to survive for over five long years.

When the effects of sensory deprivation set in after a year or so of extreme isolation, any and all stimuli became sensory overload. Simple things such as a change in cell locations or even a trip to the doctor were completely overwhelming and hard to deal with. It made me want to hide or close my eyes. The sudden assault of enraging sensory stimuli - the sound of loud doors opening and closing all day and night, flashlights in your eyes all night, 24-hour light in your cell, keys jingling on the guard's belt - all became much too loud and much too annoying. Intercoms and loudspeakers in the cells and pods would emit very loud noises and voices all day and night. The sounds become very overwhelming and they never went away. The visual and auditory senses would, at times, become overloaded to the point where I wanted the noise to stop. Yet I remained starved of taste, smell, and touch. It was a feeling of having nothing and having too much all 
Journal of Prisoners on Prisons, Volume 23(1), 2014

at the same time. I can see how some prisoners went mad as a result. If I had not fought inside my mind, I might have lost myself altogether.

For me social interaction became non-existent after three years in isolation. It became too much to handle. Even simple conversation with a guard or a prisoner down the tier was so mentally challenging and overwhelming I chose not to engage in it. Being by myself and keeping to myself was all I felt comfortable doing. It was as if my environment did not isolate me enough from others and after even more time I began to isolate myself from myself. It is no mystery that humans are social animals. Our whole social identity is formed based on our social interaction with others.

Psychology professor Harry Harlow tested the social impact of isolation with baby rhesus monkeys. The researchers found that upon being released into a group of ordinary monkeys the test monkeys "usually go into a state of emotional shock, characterized by ... autistic self-clutching and rocking, 12 months of isolation almost completely obliterated the animals socially" (Gawande, 2012, p. 2). Moreover, "EEG studies going back to the 1960's have shown diffuse slowing of brain waves in prisoners after a week or more of solitary confinement reports the New Yorker"(ibid, p. 3). Another professor, Craig Haney, from the University of California Santa Cruz, notes "that after months or years of complete isolation many prisoners begin to lose the ability to initiate behavior of any kind - to organize their own lives around activity and purpose. Chronic apathy, lethargy, depression, and despair often result... in extreme cases prisoners may literally stop behaving, becoming essentially catatonic" (ibid, p. 5). Haney also found " that $90 \%$ of these prisoners had difficulties with irrational anger compared with just 3\% of the general population", which he linked "to the extreme restriction, the totality of control and the extended absence of any opportunity for happiness of joy" (ibid).

When you completely lose the capacity to make any choice for yourself and can make no choices for yourself or your survival, your mind begins to do something that you have little control over - it begins to crack. Pacing is what prisoners called it. Walking back and forth from the bed to the door, the door to the bed for a couple of hours every day; it was a terrible feeling, yet it was a means of escape. It took my mind outside those four walls for a little while. Day after day it felt like the wall that kept me in were the same walls that seem to be closing in on my mind, trying to suffocate my very being. There was no social interaction - no pleasure of relationships, no talking, no touching, and no laughing. The majority of happiness one achieves or experiences during his or her life-time is usually attributed to the friendship or 
the relationships that they have. When I became stripped of that I lost all sense of joy. My feelings evolved into a state of sadness that later morphed into fullon loneliness and depression. I began to shut down mentally and physically.

After several years in solitary confinement I had adjusted to the lack of everything. My socially nonexistent world became routine, so my return to the world outside the prison became a lot more challenging. I had lost the majority of my social skills. Upon my release from solitary after 56 months I experienced feelings and sensations I had never felt before: extreme paranoia, anxiety, nervousness, vulnerability and loss of confidence in all social situations. I could not hold face-to-face conversations, could not be in small rooms, could not be around more than four to five people at a time, and even felt very nervous being in public places. These are feelings no human should ever feel.

I have always been a very social person, loved talking to people, and interacting with those around me, but these days, eight months after my release, I still lack complete confidence in many social situations. I still like to sit with my back in the corner of a room, but I am getting better. My hands still sweat when I meet someone I do not know and I am still a bit hesitant to engage in face-to-face conversations with total strangers. However, with a strong desire to get all my social skills back I try to do all these things as often as possible. I am adjusting to normal life outside the tomb of isolation, but I am scared my life will never be in full fashion, never again back to the "normal" so many people take for granted.

My solitary confinement experience was the hardest thing I had ever endured up to that point in my life. Adjusting to life in society, being around people and accepting new responsibilities is even harder. Yet because of my struggle I have found strength I never knew I had and am now an even firmer believer in free will. Because of my five years in the box my life is now better than it has ever been, mainly because I value and appreciate everything, every little experience. From a simple sunrise to the ability to make choices for myself, normal sensory input and social interaction on a daily basis make life so grand. Living with nothing teaches you to appreciate everything, and I mean everything. Being deprived and flooded with sensory stimulation at the same time is very detrimental to one's psychological state. Being exposed to solitary conditions is both physically and emotional damaging, and the short- and long-term impact of the deterioration of social skills is the harshest of all. Anxiety, nervousness, headaches, chronic tiredness, loss of sleep, trouble sleeping, impending nervous breakdown, perspiring hands, 
loss of appetite, dizziness, nightmares, and shaky hands are some of the symptoms of psychological and emotional trauma I experienced.

Articles regarding solitary confinement and the effects of prison show that I am not the only one who went through hell (see Piché and Major, forthcoming), both during my time in isolation and after my release. The psychopathological effects of prolonged isolation are ruminations, irrational anger, over sensitivity to stimuli, confused thought processes, social withdrawal, chronic depression, emotional flatness, crazy mood swings, overall deterioration, talking to yourself, violent fantasies, perceptual distortions, hallucinations and suicidal thoughts. For five years I was buried alive. My body was in prison, my mind in hell, and although, upon my release my body was allowed to leave my cement tomb, my mind continued and still continues to be trapped inside a prison created by isolation and sensory deprivation. "Living behind these and inside those four small walls is a nightmare that never goes away! Many of us behind these walls are going crazy in record numbers and are becoming more damaged and more violent than we have ever been in our whole lives. What good is that to society?" (California SHU Prisoner in Magnani, 2008, p. 9). In spite all of it all, I will rise!

\section{REFERENCES}

Gawande, Atul (2012) "Hellhole", The New Yorker - Annals of Human Rights.

Kamel, Rachel and Bonnie Kerness (2003) The Prison Inside the Prison: Control Units,

Supermax Prisons, and Devices of Torture, Philadelphia: American Friends Service Committee.

Magnani, Laura (2008) Buried Alive: Long-Term Isolation in California's Youth and Adult Prisons, Oakland: American Friends Service Committee.

Piché, Justin and Karine Major (forthcoming) "Prisoner Writing in/on Solitary Confinement: Contributions from the Journal of Prisoners on Prisons, 1988-2013", Canadian Journal of Human Rights.

Weiten, Wayne (2008) Psychology: Scenes and Variations ( $8^{\text {th }}$ edition), Belmont: Wadsworth.

\section{ABOUT THE AUTHOR}

Anonymous is now a former Colorado state prisoner who runs his own successful catering business in the United States. Having survived solitary confinement, he is working through the transition of living a life where his senses are fully engaged, including as a first-time father of a soon to be born baby girl. 